\title{
Effect of Chromium on Glucose and Lipid Profiles in Patients with Type 2 Diabetes; A Meta-analysis Review of Randomized Trials
}

\author{
Mohammad Abdollahi ${ }^{3}$, Amir Farshchi ${ }^{1}$, Shekoufeh Nikfar ${ }^{1,2}$, Meysam Seyedifar ${ }^{1}$ \\ ${ }^{1}$ Department of Pharmacoeconomics and Pharmaceutical Administration, Faculty of Pharmacy, Tehran University of \\ Medical Sciences, Tehran, Iran. \\ ${ }^{2}$ Food and Drug Organization, Ministry of Health and Medical Education, Tehran, Iran. \\ ${ }^{3}$ Department of Toxicology and Pharmacology, Faculty of Pharmacy, and Pharmaceutical Sciences Research Center, \\ Tehran University of medical Sciences, Tehran, Iran.
}

Received, January 29, 2013; Revised, March 26, 2013; Accepted, April 19, 2013; Published, April 20, 2013.

\begin{abstract}
Purpose. Chromium (Cr) as an essential trace element in metabolism of carbohydrate, lipid and protein is currently prescribed to control diabetes mellitus (DM). The objective of this meta-analysis was to compare the effect of $\mathrm{Cr}$ versus placebo (Pl) on glucose and lipid profiles in patients with type $2 \mathrm{DM}$. Methods. Literature searches in PubMed, Scopus, Scirus, Google Scholar and IranMedex was made by use of related terms during the period of 2000-2012. Eligible studies were randomized clinical trials (RCTs) with intake of Cr higher than $250 \mu \mathrm{g}$ at least for three months in type $2 \mathrm{DM}$. Glycated hemoglobin (HbA1c), fasting blood sugar (FBS), total cholesterol (TC), high-density lipoprotein cholesterol (HDL-C), low-density lipoprotein cholesterol (LDL-C), very low-density lipoprotein cholesterol (VLDL-C), triglyceride (TG), and body mass index (BMI) were the main outcomes. Results. Seven out of 13 relevant studies met the criteria and were included in the meta-analysis. HbA1c change in diabetic patients in $\mathrm{Cr}$ supplement therapy comparing to $\mathrm{Pl}$ was -0.33 with $95 \% \mathrm{CI}=-0.72$ to $0.06(\mathrm{P}=0.1)$. Change of $\mathrm{FBG}$ in $\mathrm{Cr}$ therapy vs. $\mathrm{Pl}$ was -0.95 with $95 \% \mathrm{CI}=-1.42$ to $-0.49(\mathrm{P}<$ $0.0001)$. TC change in $\mathrm{Cr}$ therapy vs. $\mathrm{Pl}$ was 0.07 with $95 \% \mathrm{CI}=-0.16$ to $0.31(\mathrm{P}=0.54)$. TG change in diabetic patients in $\mathrm{Cr}$ supplement therapy comparing to $\mathrm{Pl}$ was -0.15 with $95 \% \mathrm{CI}=-0.36$ to $0.07(\mathrm{P}=0.18)$. Conclusions. $\mathrm{Cr}$ lowers FBS but does not affect $\mathrm{HbA1c}$, lipids and BMI.
\end{abstract}

This article is open to POST-PUBLICATION REVIEW. Registered readers (see "For Readers") may comment by clicking on ABSTRACT on the issue's contents page.

\section{INTRODUCTION}

Diabetes mellitus (DM) is a serious health problem with the high financial and societal impression on health systems (1). A significant increase in costs of long-term treatment of diabetes and its complications is felt (2). Change in lifestyle, use of proper safe diets, cost of drugs, use or not use of supplements and adjuvant therapies are among current concerns, and thus strategies are being designed to control DM (3). In the recent years, many natural products or antioxidants have been proposed for management of DM (4) but costeffectiveness of most of them is under debate. Some experts believe that use of antioxidant supplementary regimens help synthetic drugs to better work in the way to reduce total treatment cost (5).
Trivalent chromium $(\mathrm{Cr})$ as an essential trace element in metabolism of carbohydrate, lipid and protein is currently prescribed by some clinicians in an aim to control DM $(6,7)$. Previous studies have shown that $\mathrm{Cr}$ could light up insulin receptors, stimulate the liver enzyme glucokinase, and enhance pancreatic B islets (8). It is proposed that Cr can complex to Glucose Tolerance Factor (GTF) in the yeast and in low molecular weight Cr-like substance (LMWCr) in animal cells (9). In 1959, it was shown that $\mathrm{Cr}$ III as an active component of

\footnotetext{
Corresponding Author: Mohammad Abdollahi, Department of Toxicology and Pharmacology, Faculty of Pharmacy, and Pharmaceutical Sciences Research Center, Tehran University of medical Sciences, Tehran 1417614411, Iran; Email: Mohammad.Abdollahi@UToronto.Ca Mohammad@TUMS.Ac.Ir
} 
GTF could control the impaired glucose tolerance in rats fed diets with Cr. In 1977, for the first time in human studies, it was shown that severe diabetic symptoms in a female patient could be relieved with Cr III in parenteral nutrition (10). From 1977 up to now, many articles have noticed some positive effects of $\mathrm{Cr}$ on human and animals. Despite the presence of reviews on $\mathrm{Cr}$, the net effect of $\mathrm{Cr}$ has not been clarified yet because of lots of reasons, including studies which did not exclusively examine type $2 \mathrm{DM}$, differences in the outcomes or study population, low quality, and duration of treatment. In addition, some studies were nonrandomized. Regarding these deficits and in the line of our idea (11), we aimed to conduct this metaanalysis to clarify the effect of $\mathrm{Cr}$ versus $\mathrm{Pl}$ on the glucose and lipid profiles among type $2 \mathrm{DM}$ patients.

\section{METHODS}

Literature searches in electronic databases such as PubMed, Scopus, Scirus, Google Scholar and IranMedex was made using terms such as diabetes, type 2 diabetes, insulin, insulin sensitivity, chromium, chromium picolinate, yeast, glycemic control, lipid profile, supplementary, hemoglobin $\mathrm{A} 1 \mathrm{C}(\mathrm{HbAlc})$ and randomized clinical trial (RCT) during the period of 2000-2012. Eligible studies were RCTs of $\mathrm{Cr}$ with intake of $\geq 250 \mu \mathrm{g}$ at least for three months among type $2 \mathrm{DM}$. Two reviewers independently screened abstracts and full papers. Primary outcomes of interest were $\mathrm{HbAlc}$ and fasting blood sugar (FBS). Secondary outcomes were total cholesterol (TC), high-density lipoprotein cholesterol (HDL-C), low-density lipoprotein cholesterol (LDL-C), very low-density lipoprotein cholesterol (VLDL-C), triglyceride (TG), and body mass index (BMI). All duplicated articles and any paper, which did not meet our inclusion criteria, were excluded.

\section{Assessment of trial quality}

Jadad score, which indicates the quality of the studies based on their description of randomization, blinding, and dropouts (withdrawals) was used to assess the methodological quality of trials (12). The quality scale ranged from 0 to 5 points with a low quality report of score 2 or less and a high quality report of score at least 3. (Table 1).

\section{STATISTICAL ANALYSIS}

Data from selected studies were extracted in the form of $2 \times 2$ tables by study characteristics. Included studies were weighted by effect size and pooled. Data were analyzed using StatsDirect version 2.7.9. Standardized effect size and 95\% confidence intervals $(95 \% \mathrm{CI})$ were calculated using Mulrow-Oxman (for fixed effects) or Der Simonian-Laird (for random effects) methods. The Cochran Q test was used to test heterogeneity and $\mathrm{P}<0.05$ was considered significant. In case of heterogeneity, the random effects model was used. Funnel plot was used as publication bias indicator.

\section{RESULTS}

According to related key words for $\mathrm{Cr}$ clinical studies, there were 230 studies cited in PubMed, Scopus, Scirus, Google Scholar and IranMedex. (Figure 1). Two hundred and seventeen studies were excluded because of the following reasons; studies which did not exclusively studied type 2 DM, different outcome measures, improper study population, and non-randomization. (Table 2). Of the 13 related studies, 6 were rejected because of short duration of treatment (less than 3 months) and one because of low quality in scale of Jadad score. Finally seven studies were included in the metaanalysis. (Table 3 ).

\section{Effect of Cr on HbA1c in diabetic patients}

The summary for effect size of weighted mean differences of HbA1c change " $\triangle \mathrm{HbA1} c$ " in diabetic patients in $\mathrm{Cr}$ supplement therapy for seven included trials comparing to $\mathrm{Pl}$ (13-19) was -0.33 with $95 \% \mathrm{CI}=-0.72$ to $0.06(\mathrm{P}=0.1$, Figure $2-\mathrm{a})$. The Cochrane Q test for heterogeneity indicated that the studies are heterogeneous $(\mathrm{P}=0.01)$ and could not be combined, thus the random effects for individual and summary of effect size for weighted mean differences was applied. For evaluation of publication, Egger bias regression of normalized effect vs. precision for all included studies for " $\triangle \mathrm{HbA} 1 \mathrm{c} "$ in diabetic patients among $\mathrm{Cr}$ supplement vs. $\mathrm{Pl}$ therapy was $-1.9(95 \% \mathrm{CI}=-4.3$ to $0.45, \mathrm{P}=0.1$ ) and Begg-Mazumdar Kendall's test on standardized effect vs. variance indicated tau $=$ $0.29, \mathrm{P}=0.28$ (Figure 2-b, unbiased meta-analysis). 


\begin{tabular}{lccccc}
\hline \multicolumn{6}{c}{ Table 1. Quality score of randomized controlled trial included in the meta-analysis } \\
\hline \multicolumn{1}{c}{ Study } & Randomization & Blinding & Factors and Jadad scores & Withdrawals and dropouts & Total Jadad score \\
\hline Cefalu et al., (13) & 2 & 2 & 1 & 5 \\
Lai, (17) & 2 & 2 & 1 & 5 \\
Kleefstra et al., (15) & 2 & 2 & 1 & 5 \\
Martin et al., (18) & 2 & 2 & 1 & 5 \\
Kleefstra et al., (16) & 2 & 2 & 1 & 5 \\
Racek et al., (19) & 2 & 2 & 0 & 4 \\
Ghosh et al., (14) & 2 & 2 & 1 & 5 \\
\hline
\end{tabular}

Potentially relevant reports identified and screened

for retrieval from el ectronic search:

3 from IranMedex

68 from Fubled

21 from cochrane

25 from scopus

18 from scirus

95 from Google Schalar

133 excluded because of duplication.

84 reports excluded on the basis of the title and abstract and limitation to RCTs.

5 repots excluded because of chromium intake of $\_3$ months.

8 repots eligible articles consider for evaluating clinical effect of chromium on glucose and lipid profiles.

Figure 1. Flow diagram of the study selection process. 


\section{Effect size meta-analysis plot [random effects]}

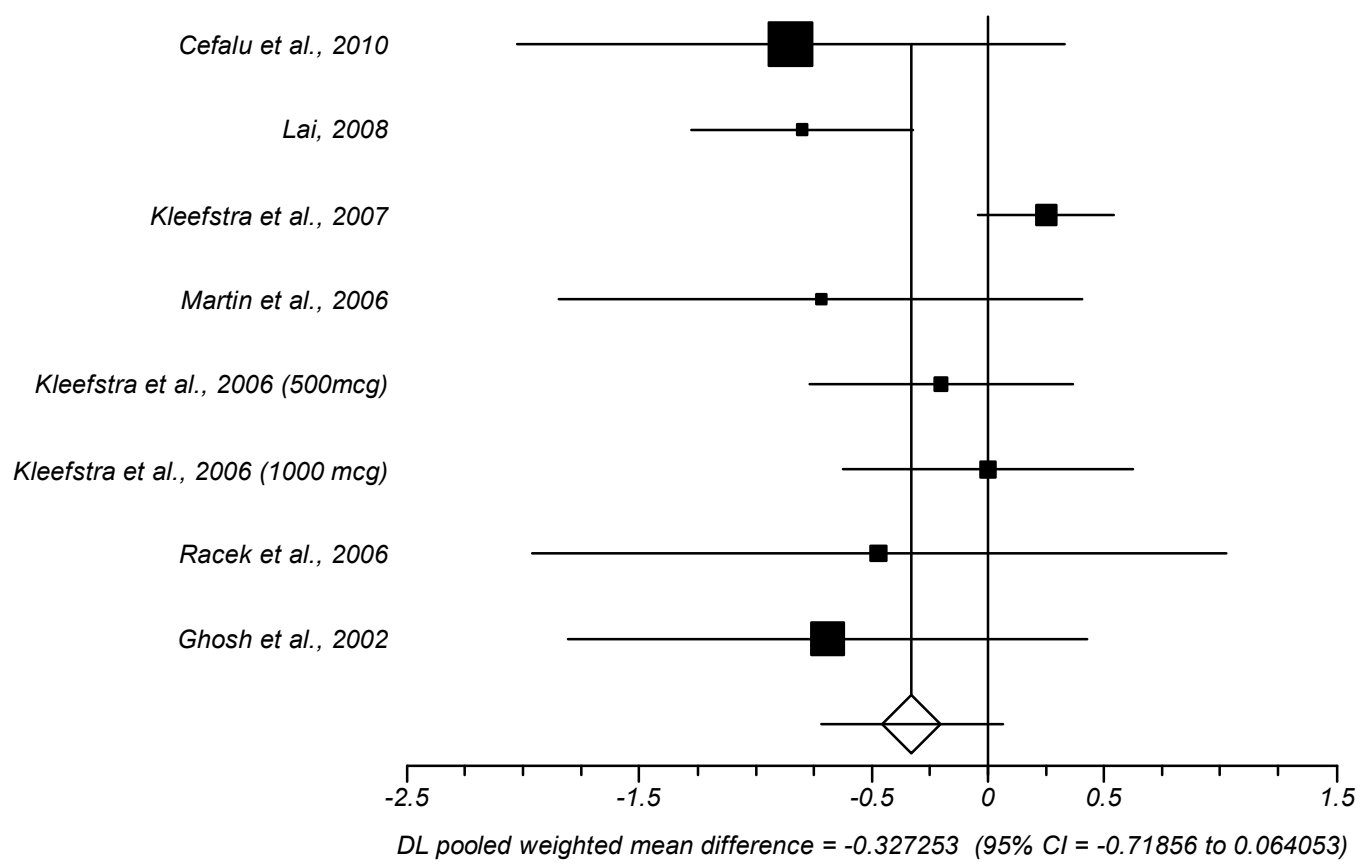

Figure 2-a. Individual and pooled effect size for weighted mean differences for the outcome of " $\Delta \mathrm{HbA} 1 \mathrm{c}$ " in the studies considering chromium supplement comparing to placebo therapy for diabetic patients

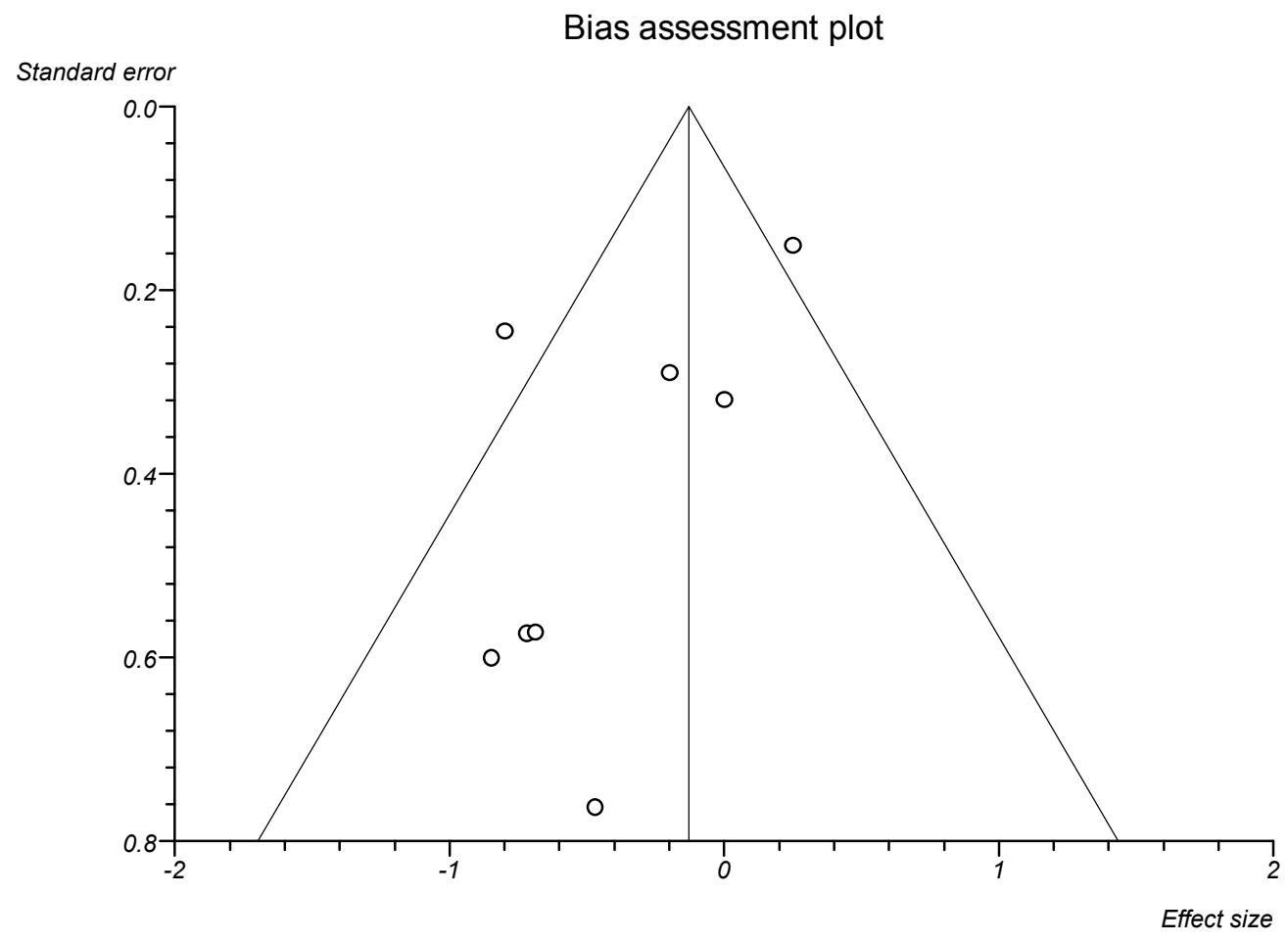

Figure 2-b. Publication bias indicators for the outcome of " $\Delta \mathrm{HbA} 1 \mathrm{c}$ " in the studies considering chromium supplement comparing to placebo therapy for diabetic patients 


\section{Effect of $\mathrm{Cr}$ on FBG in diabetic patients}

The summary for effect size of weighted mean differences of FBG change " $\triangle F B G$ " in diabetic patients in $\mathrm{Cr}$ supplement therapy for six included trials comparing to $\mathrm{Pl}(13-15,17-19)$ was -0.95 with $95 \% \mathrm{CI}=-1.42$ to $-0.49(\mathrm{P}<0.0001$, Figure $3-\mathrm{a})$. The Cochrane $\mathrm{Q}$ test for heterogeneity indicated that the studies are not heterogeneous $(\mathrm{P}=0.3)$ and could be combined, thus the fixed effects for individual and summary of effect size for weighted mean differences was applied. For evaluation of publication Egger bias regression of normalized effect vs. precision for all included studies for " $\triangle \mathrm{FBG}$ " in diabetic patients among $\mathrm{Cr}$ supplement vs. $\mathrm{Pl}$ therapy was $=0.43(95 \% \mathrm{CI}=-0.04$ to $4.9, \mathrm{P}=$ $0.81)$ and Begg-Mazumdar Kendall's test on standardized effect vs. variance indicated tau $=0.2$, $\mathrm{P}=0.72$ (Figure 3-b, unbiased meta-analysis).

\section{Effect of $\mathrm{Cr}$ on $\mathrm{TC}$ in diabetic patients}

The summary for effect size of weighted mean differences of TC change " $\triangle \mathrm{TC}$ " in diabetic patients in $\mathrm{Cr}$ supplement therapy for four included trials comparing to $\mathrm{P} 1$ retrieved from three studies (14-16) was 0.07 with $95 \% \mathrm{CI}=-0.16$ to $0.31(\mathrm{P}=0.54$, Figure 4-a). The Cochrane $\mathrm{Q}$ test for heterogeneity indicated that the studies are not heterogeneous $(\mathrm{P}=$ 0.24 ) and could be combined, thus the fixed effects for individual and summary of effect size for weighted mean differences was applied. For evaluation of publication, Egger bias regression of normalized effect vs. precision for all included studies for " $\triangle \mathrm{TC}$ " in diabetic patients among $\mathrm{Cr}$ supplement vs. $\mathrm{Pl}$ therapy was $=-2.11(95 \% \mathrm{CI}=-$ 3.73 to $-0.5, \quad \mathrm{P}=0.03)$ and Begg-Mazumdar Kendall's test on standardized effect vs. variance indicated tau $=-0.67, \mathrm{P}=0.08$ (Figure 4-b, unbiased meta-analysis).

\section{Effect size meta-analysis plot [fixed effects]}

Cefalu et al., 2010

Lai, 2008

Kleefstra et al., 2007

Martin et al., 2006

Racek et al., 2006

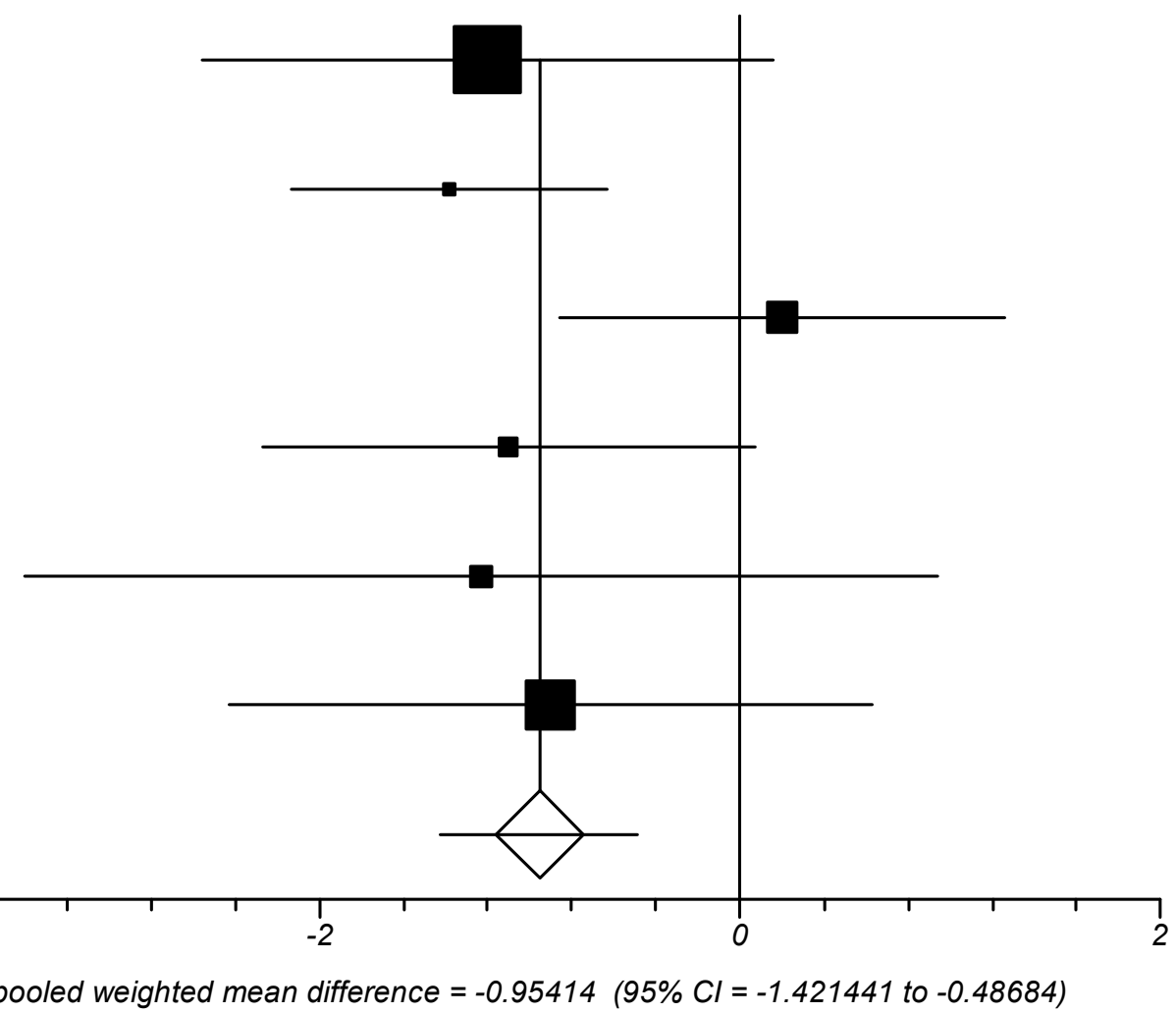

Ghosh et al., 2002

Figure 3-a. Individual and pooled effect size for weighted mean differences for the outcome of " $\Delta F G$ " in the studies considering chromium supplement comparing to placebo therapy for diabetic patients 


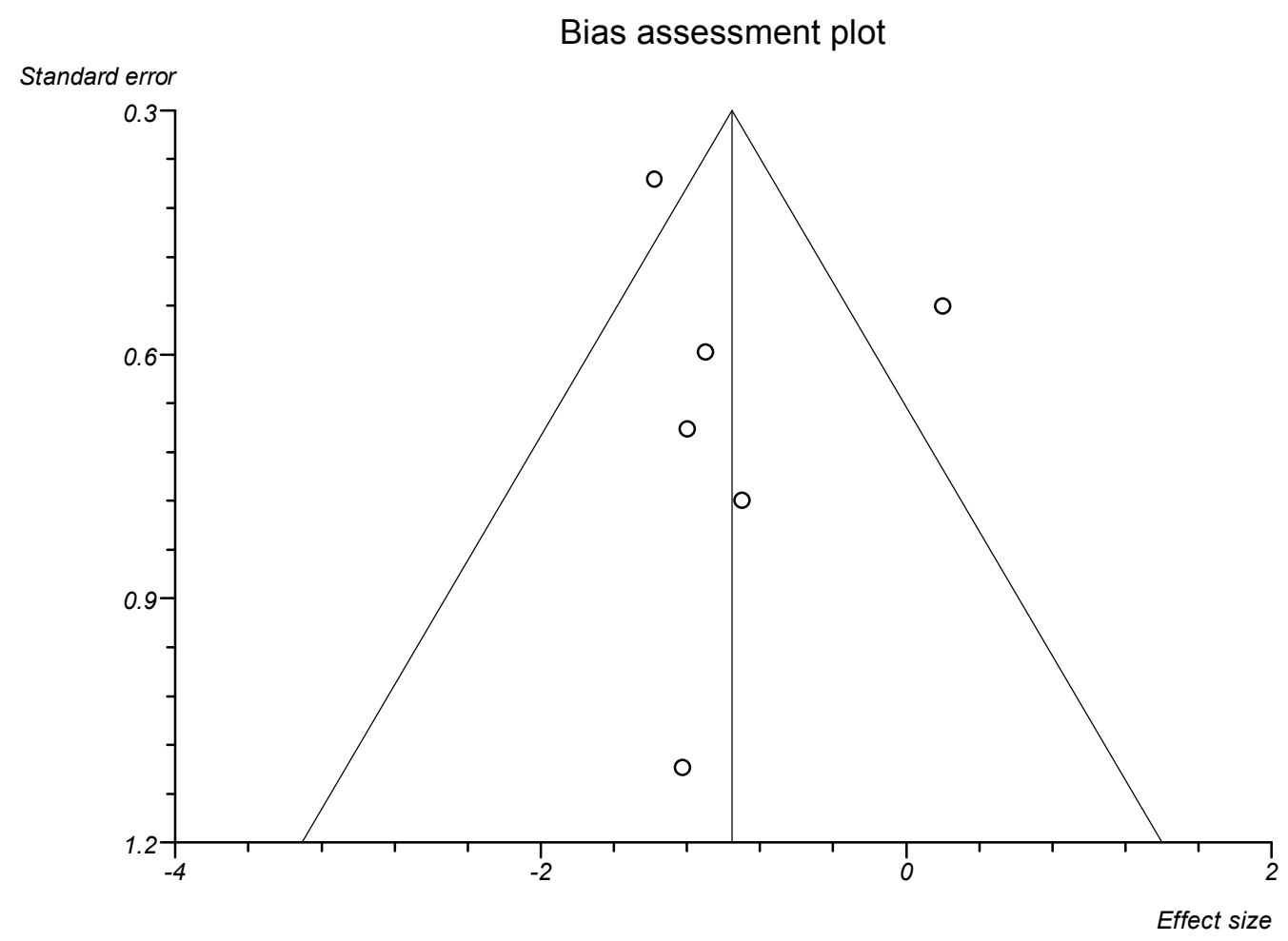

Figure 3-b. Publication bias indicators for the outcome of " $\Delta \mathrm{FG}$ " in the studies considering chromium supplement comparing to placebo therapy for diabetic patients

\section{Effect size meta-analysis plot [fixed effects]}

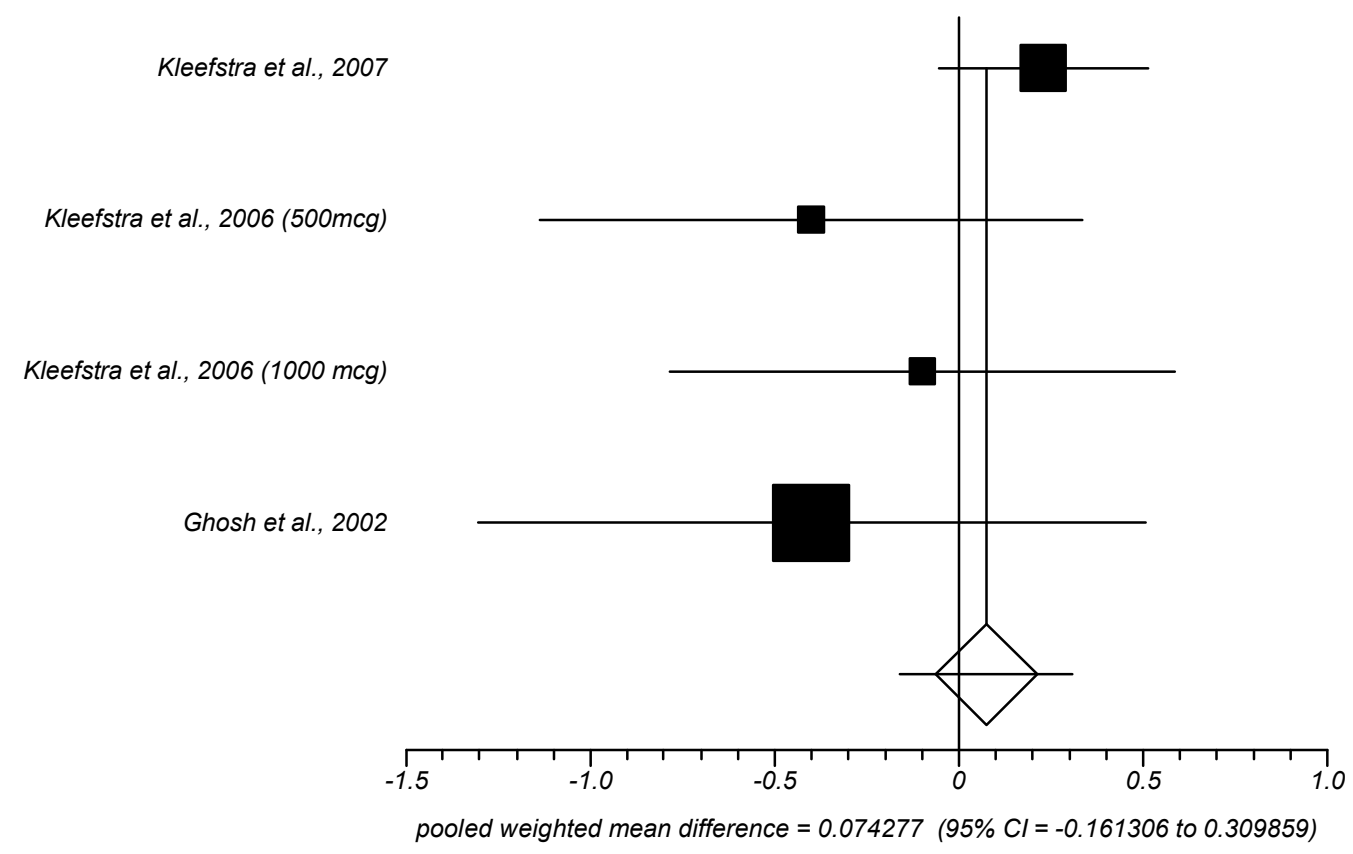

Figure 4-a. Individual and pooled effect size for weighted mean differences for the outcome of " $\Delta \mathrm{TC}$ " in the studies considering chromium supplement comparing to placebo therapy for diabetic patients 


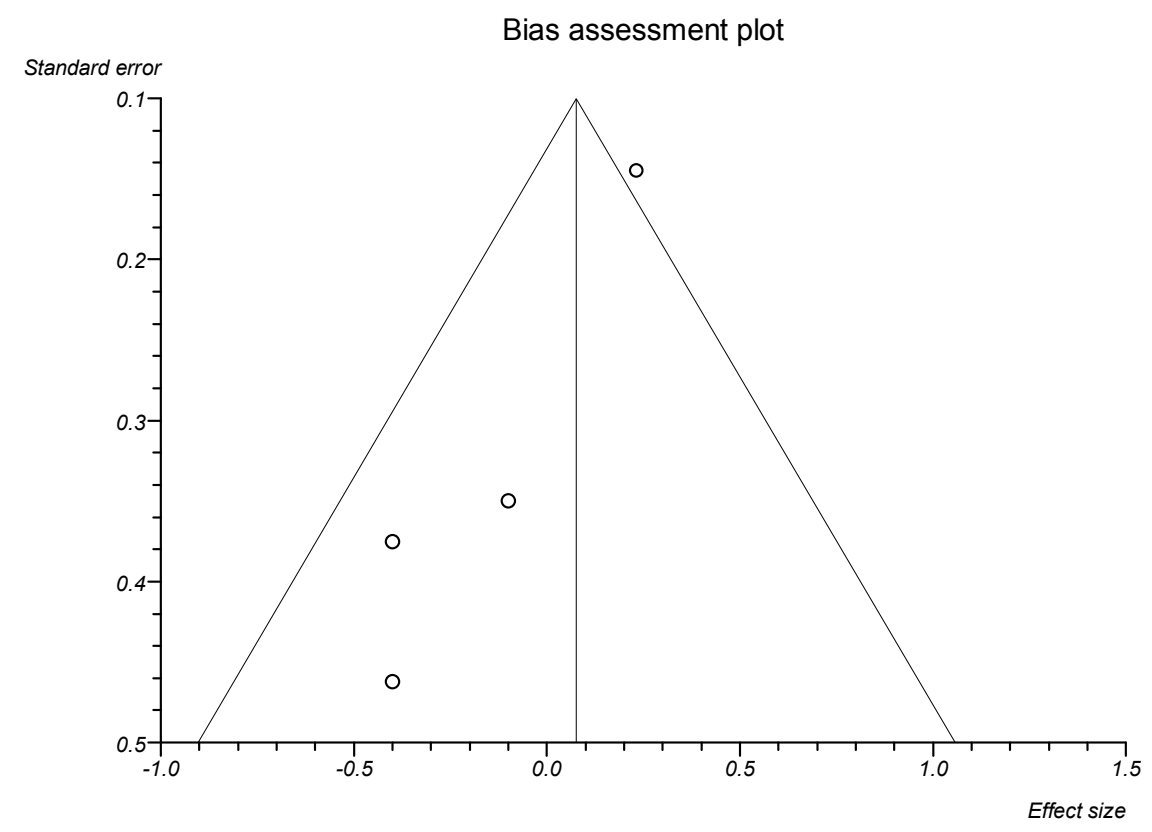

Figure 4-b. Publication bias indicators for the outcome of " $\Delta \mathrm{TC}$ " in the studies considering chromium supplement comparing to placebo therapy for diabetic patients

\section{Effect of Cr on HDL-C in diabetic patients}

The summary for effect size of weighted mean differences of HDL-C change " $\triangle \mathrm{HDL}-\mathrm{C}$ " in diabetic patients in $\mathrm{Cr}$ supplement therapy for five included trials comparing to $\mathrm{Pl}$ retrieved from four studies $(14-16,19)$ was -0.01 with $95 \% \mathrm{CI}=-0.07$ to $0.05(\mathrm{P}=0.67$, Figure 5-a). The Cochrane $\mathrm{Q}$ test for heterogeneity indicated that the studies are not heterogeneous $(\mathrm{P}=0.19)$ and could be combined, thus the fixed effects for individual and summary of effect size for weighted mean differences was applied. For evaluation of publication Egger bias regression of normalized effect vs. precision for all included studies for " $\triangle \mathrm{HDL}-\mathrm{C}$ " in diabetic patients among $\mathrm{Cr}$ supplement vs. P1 therapy was $=-1.08$ $(95 \% \mathrm{CI}=-5.39$ to $3.24, \mathrm{P}=0.49)$ and BeggMazumdar Kendall's test on standardized effect vs. variance indicated tau $=-0.6, \mathrm{P}=0.08$ (Figure 5-b, unbiased meta-analysis).

\section{Effect of Cr on LDL-C in diabetic patients}

The summary for effect size of weighted mean differences of LDL-C change " $\triangle \mathrm{LDL}-\mathrm{C}$ " in diabetic patients in $\mathrm{Cr}$ supplement therapy for five included trials comparing to $\mathrm{Pl}$ retrieved from four studies $(14-16,19)$ was -0.02 with $95 \% \mathrm{CI}=-0.19$ to 0.15 $(\mathrm{P}=0.84$, Figure 6-a). The Cochrane $\mathrm{Q}$ test for heterogeneity indicated that the studies are not heterogeneous $(\mathrm{P}=0.06)$ and could be combined, thus the fixed effects for individual and summary of effect size for weighted mean differences was applied. For evaluation of publication Egger bias regression of normalized effect vs. precision for all included studies for " $\Delta$ LDL-C" in diabetic patients among $\mathrm{Cr}$ supplement vs. $\mathrm{Pl}$ therapy was $=-2.48$ $(95 \% \mathrm{CI}=-7.71$ to $0.76, \mathrm{P}=0.08)$ and BeggMazumdar Kendall's test on standardized effect vs. variance indicated tau $=-0.6, \mathrm{P}=0.08$ (Figure 6-b, unbiased meta-analysis).

\section{Effect of Cr on VLDL-C in diabetic patients}

The summary for effect size of weighted mean differences of VLDL-C change " $\triangle$ VLDL- $C$ " in diabetic patients in $\mathrm{Cr}$ supplement therapy for two included trials comparing to $\mathrm{Pl}(13,19)$ was -0.51 with $95 \% \mathrm{CI}=-0.93$ to $1.95(\mathrm{P}=0.49$, Figure 7$)$. The Cochrane Q test for heterogeneity indicated that the studies are not heterogeneous $(\mathrm{P}=0.15)$ and could be combined, but because of few included studies the random effects for individual and summary of effect size for weighted mean differences was applied. Evaluation of publication bias of all included studies for " $\triangle$ VLDL-C" in diabetic patients among $\mathrm{Cr}$ supplement vs. P1 therapy could not be calculated because of too few strata. 


\section{Effect size meta-analysis plot [fixed effects]}

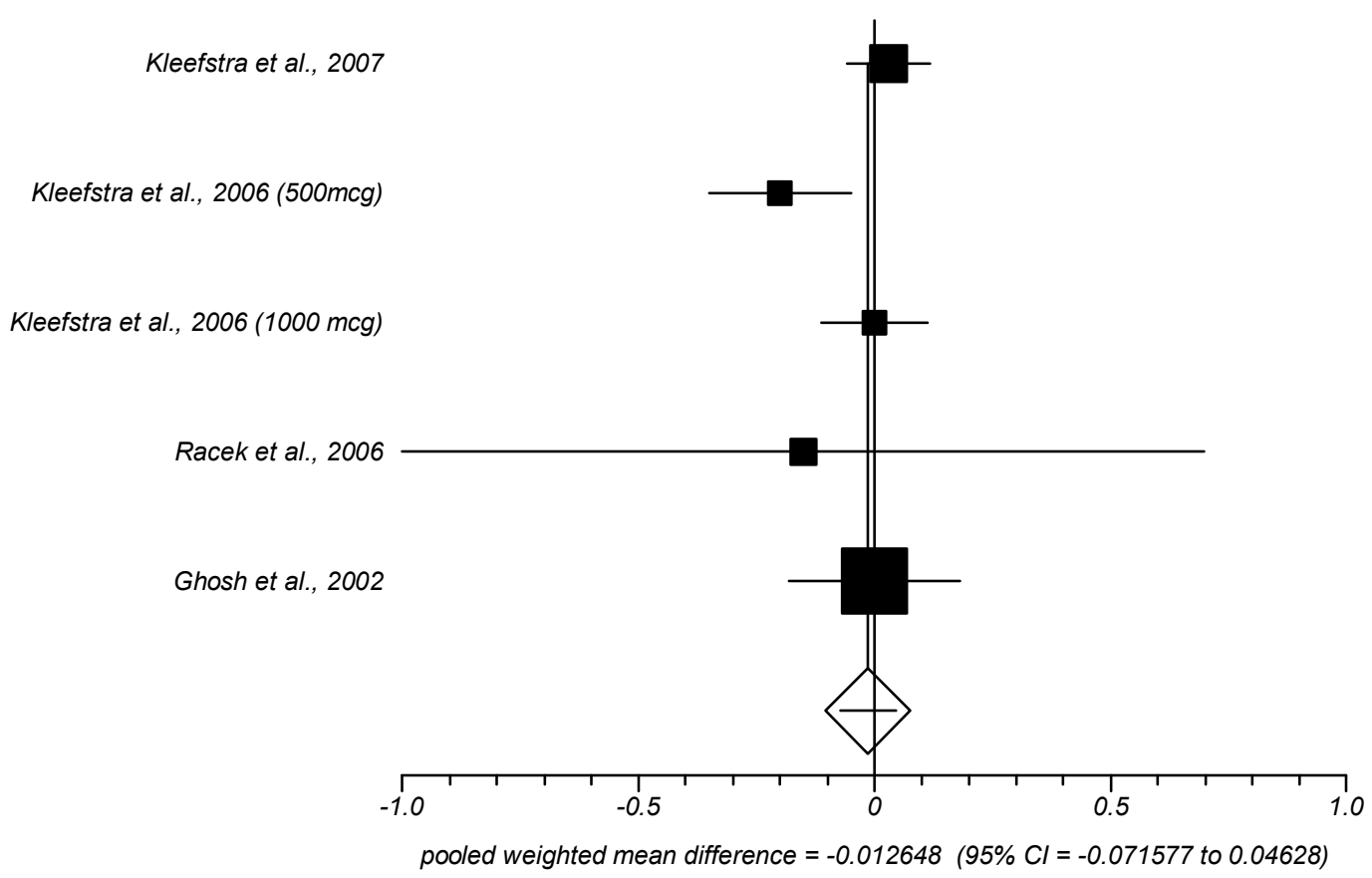

Figure 5-a. Individual and pooled effect size for weighted mean differences for the outcome of " $\Delta \mathrm{HDL}-\mathrm{C}$ " in the studies considering chromium supplement comparing to placebo therapy for diabetic patients

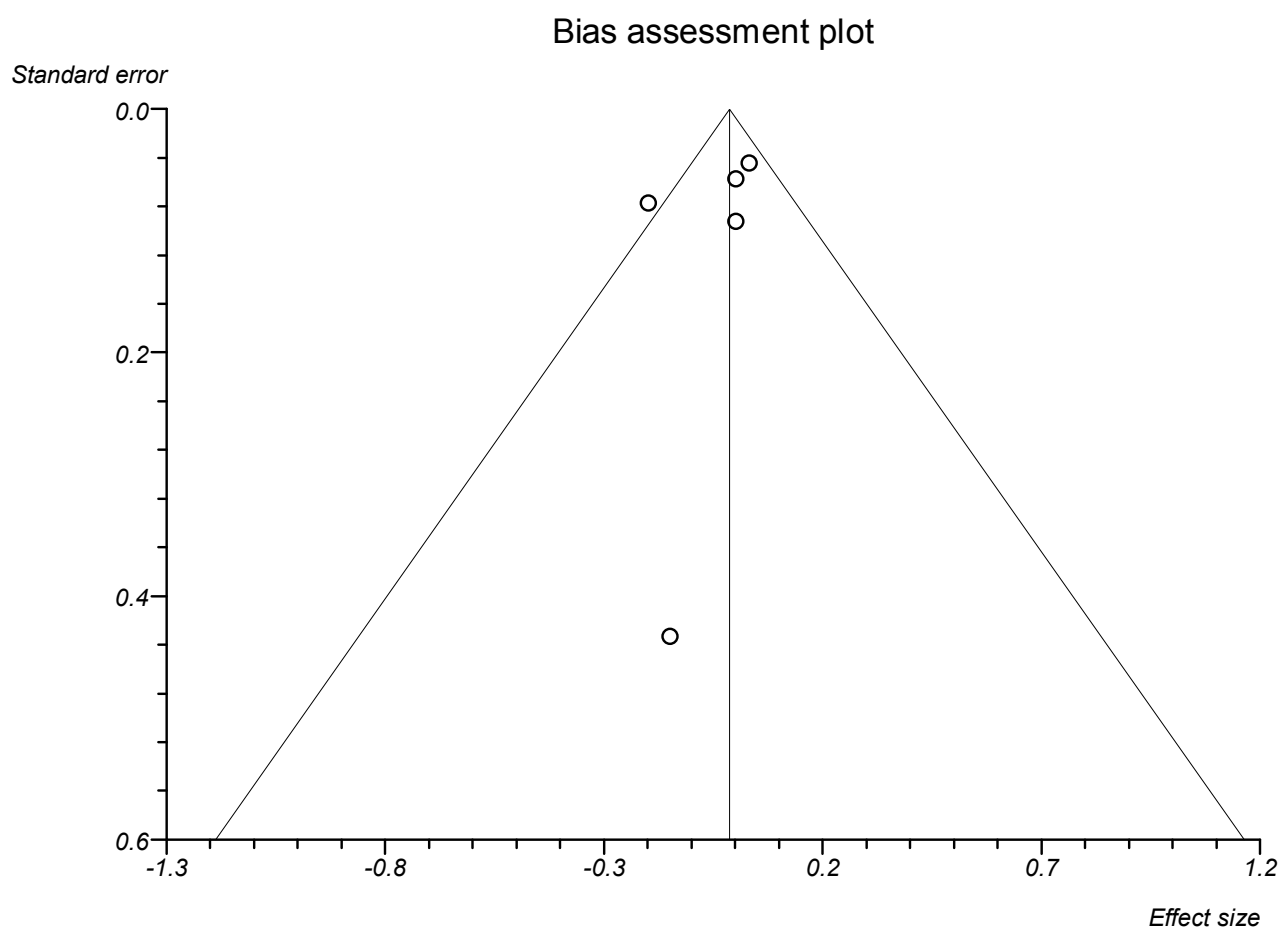

Figure 5-b. Publication bias indicators for the outcome of " $\Delta$ HDL-C" in the studies considering chromium supplement comparing to placebo therapy for diabetic patients 


\section{Effect size meta-analysis plot [fixed effects]}

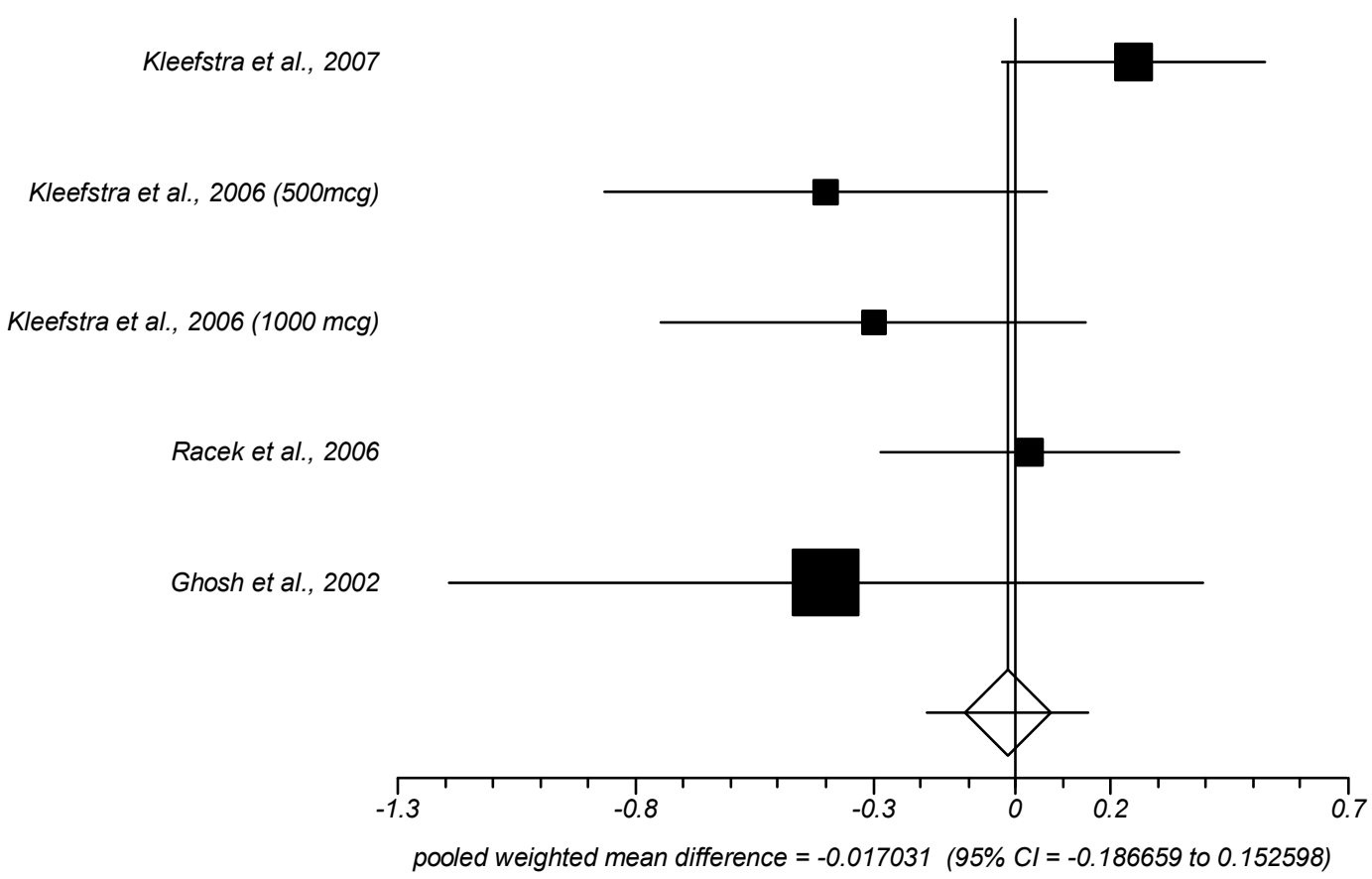

Figure 6-a. Individual and pooled effect size for weighted mean differences for the outcome of " $\Delta$ LDL-C" in the studies considering chromium supplement comparing to placebo therapy for diabetic patients

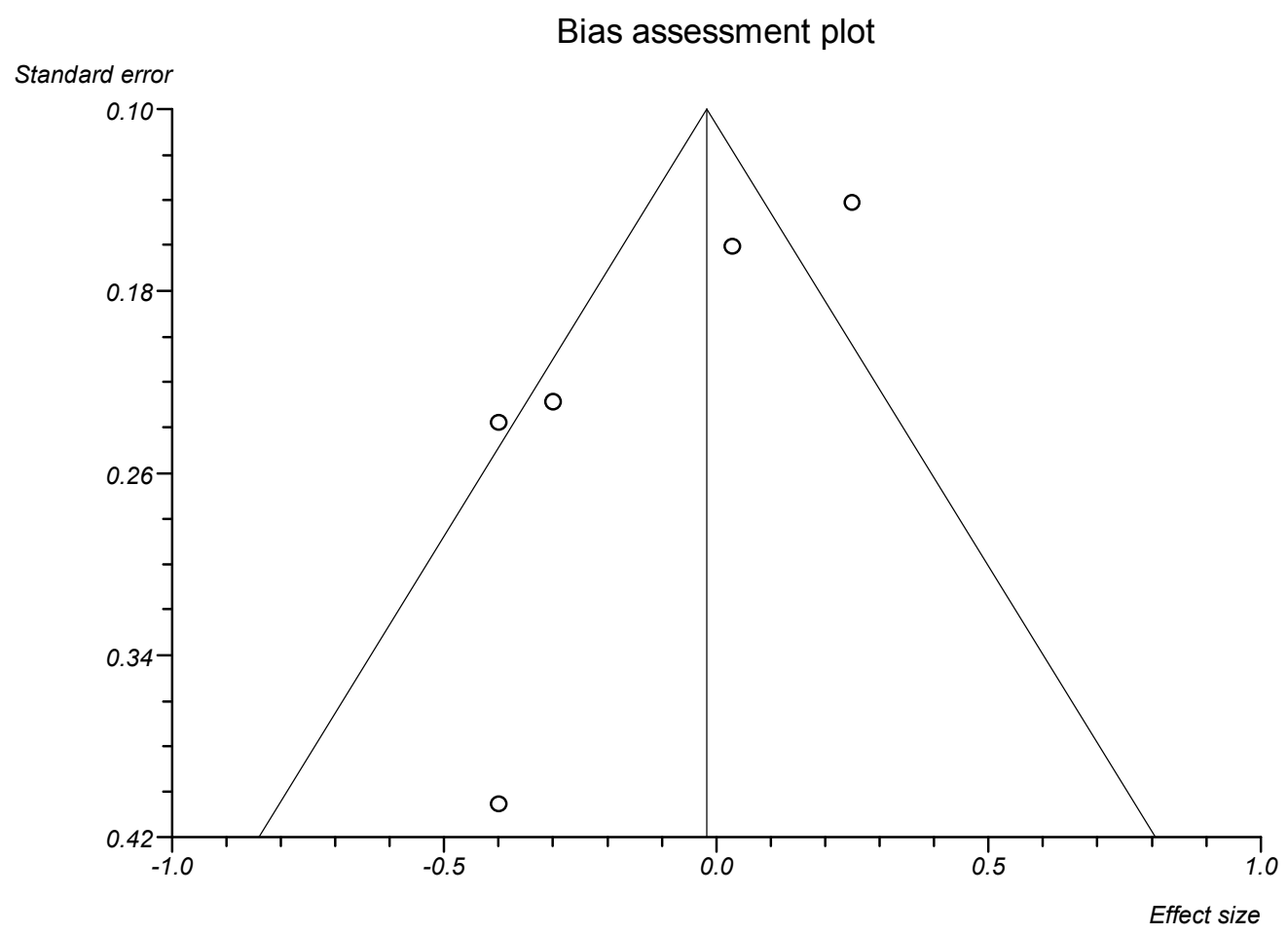

Figure 6-b. Publication bias indicators for the outcome of " $\triangle$ LDL-C" in the studies considering chromium supplement comparing to placebo therapy for diabetic patients 


\section{Effect size meta-analysis plot [random effects]}

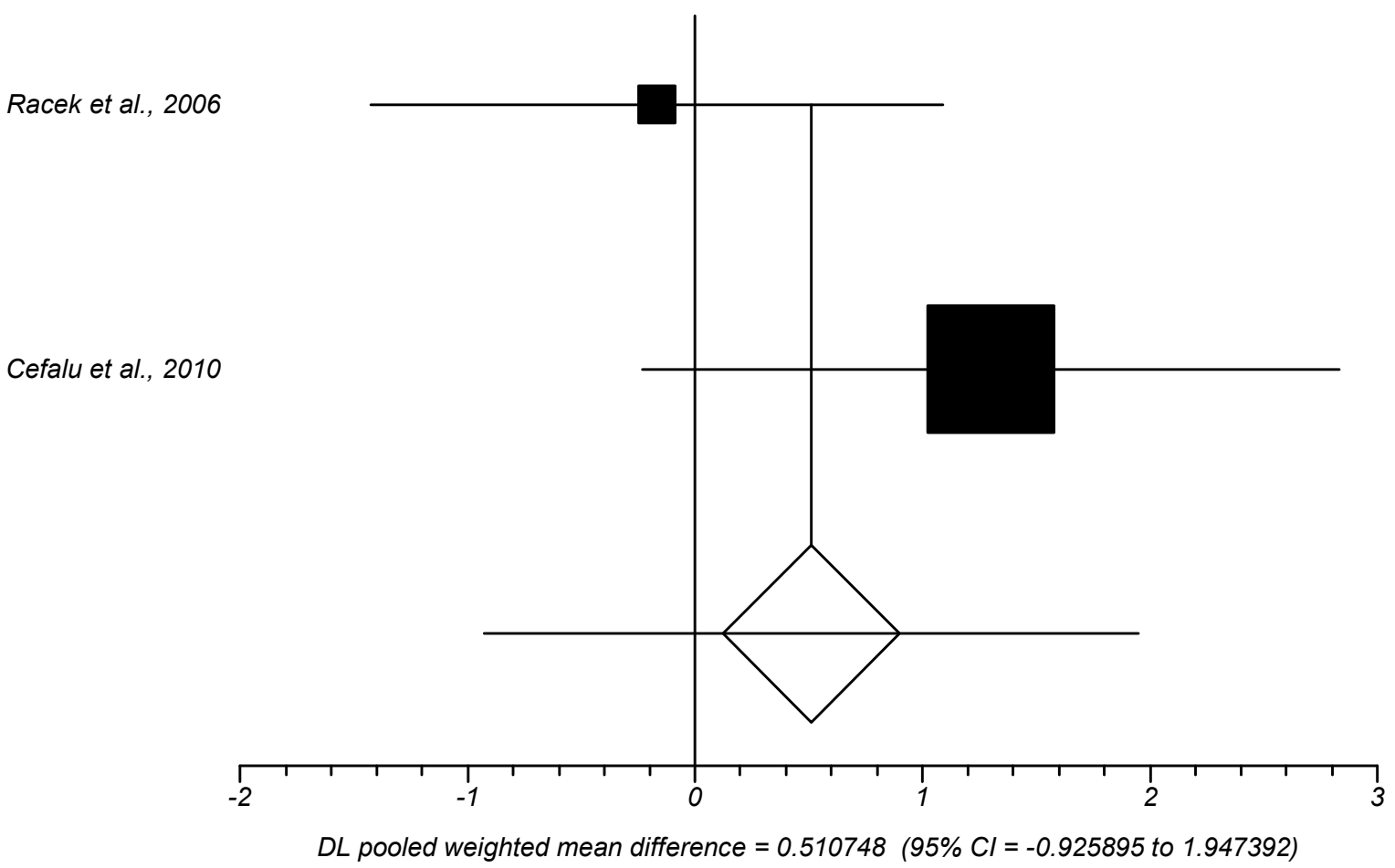

Figure 7. Individual and pooled effect size for weighted mean differences for the outcome of " $\triangle$ VLDL-C" in the studies considering chromium supplement comparing to placebo therapy for diabetic patients

\section{Effect of Cr on TG in diabetic patients}

The summary for effect size of weighted mean differences of $\mathrm{TG}$ change " $\Delta \mathrm{TG}$ " in diabetic patients in $\mathrm{Cr}$ supplement therapy for six included trials comparing to $\mathrm{Pl}$ retrieved from five studies $(14-16,18,19)$ was -0.15 with $95 \% \mathrm{CI}=-0.36$ to $0.07(\mathrm{P}=0.18$, Figure 8-a). The Cochrane $\mathrm{Q}$ test for heterogeneity indicated that the studies are not heterogeneous $(\mathrm{P}=0.85)$ and could be combined, thus the fixed effects for individual and summary of effect size for weighted mean differences was applied. For evaluation of publication Egger bias regression of normalized effect vs. precision for all included studies for " $\Delta \mathrm{TG}$ " in diabetic patients among $\mathrm{Cr}$ supplement vs. P1 therapy was $=-0.92$ $(95 \% \mathrm{CI}=-1.61$ to $-0.23, \mathrm{P}=0.02)$ and BeggMazumdar Kendall's test on standardized effect vs. variance indicated tau $=-0.6, \mathrm{P}=0.06$ (Figure 8-b, unbiased meta-analysis).

\section{Effect of Cr on BMI in diabetic patients}

The summary for effect size of weighted mean differences of BMI change " $\triangle \mathrm{BMI}$ " in diabetic patients in $\mathrm{Cr}$ supplement therapy for six included trials comparing to $\mathrm{Pl}$ retrieved from five studies $(13,15-17,19)$ was -0.07 with $95 \% \mathrm{CI}=-0.37$ to $0.23(\mathrm{P}=0.66$, Figure 9-a). The Cochrane $\mathrm{Q}$ test for heterogeneity indicated that the studies are not heterogeneous $(\mathrm{P}=0.73)$ and could be combined, thus the fixed effects for individual and summary of effect size for weighted mean differences was applied. For evaluation of publication Egger bias, regression of normalized effect vs. precision for all included studies for " $\triangle \mathrm{BMI}$ " in diabetic patients among $\mathrm{Cr}$ supplement vs. Pl therapy was $=-0.05$ $(95 \% \mathrm{CI}=-1.92$ to $1.82, \mathrm{P}=0.95)$ and BeggMazumdar Kendall's test on standardized effect vs. variance indicated tau $=-0.2, \mathrm{P}=0.47$ (Figure 9-b, unbiased meta-analysis). 


\section{Effect size meta-analysis plot [fixed effects]}

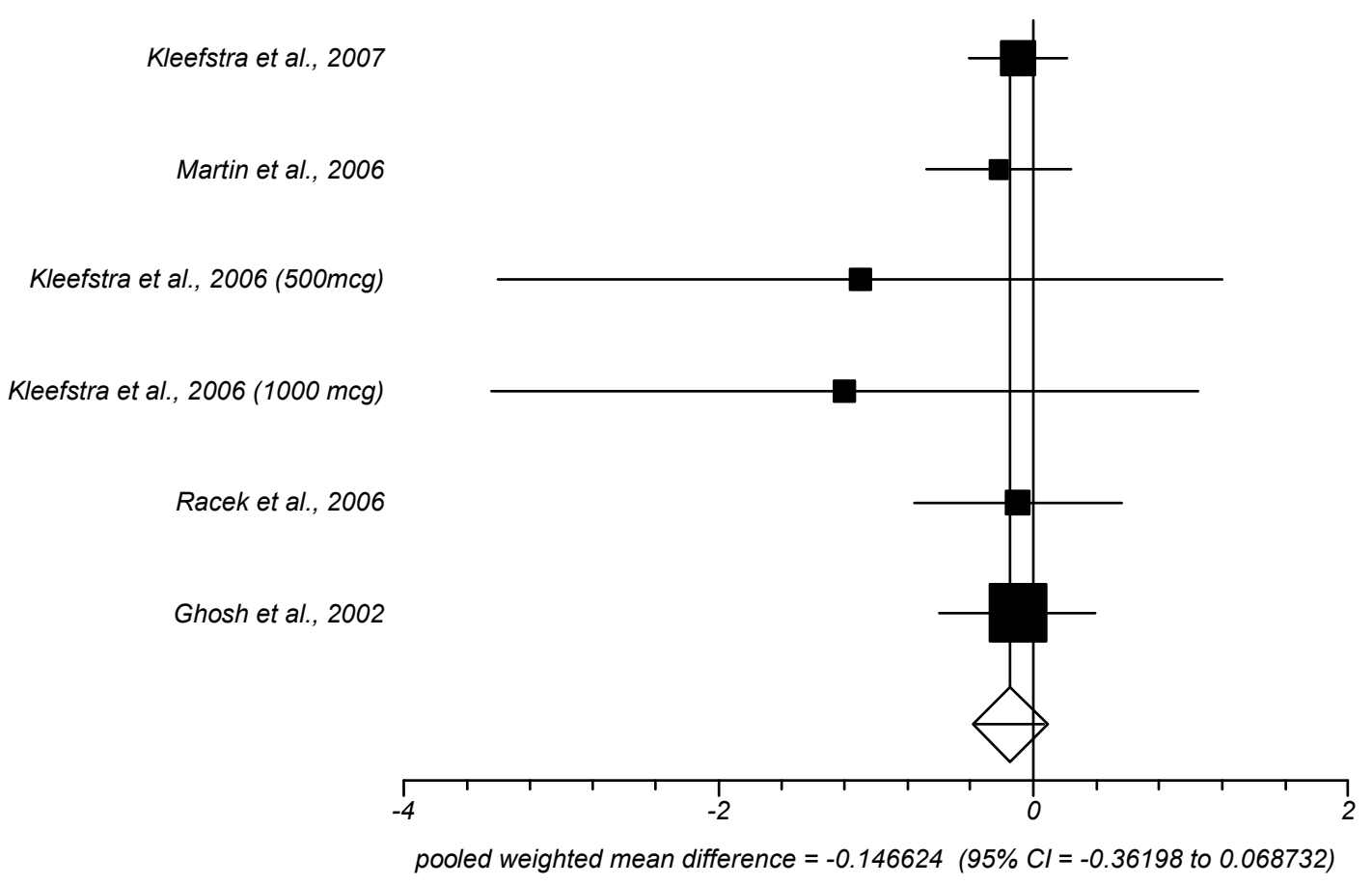

Figure 8-a. Individual and pooled effect size for weighted mean differences for the outcome of " $\Delta \mathrm{TG}$ " in the studies considering chromium supplement comparing to placebo therapy for diabetic patients

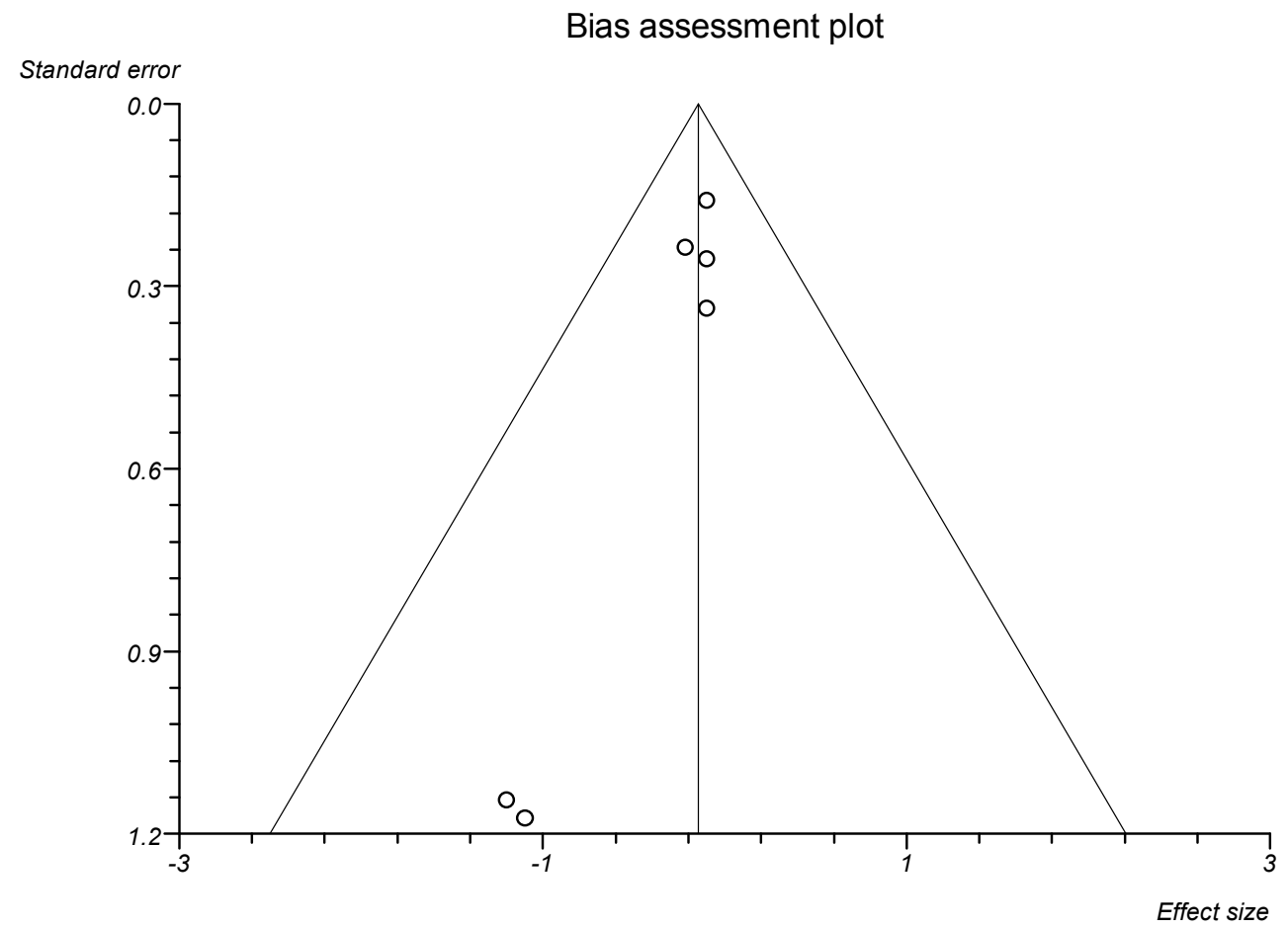

Figure 8-b. Publication bias indicators for the outcome of " $\Delta \mathrm{TG"}$ " in the studies considering chromium supplement comparing to placebo therapy for diabetic patients 


\section{Effect size meta-analysis plot [fixed effects]}

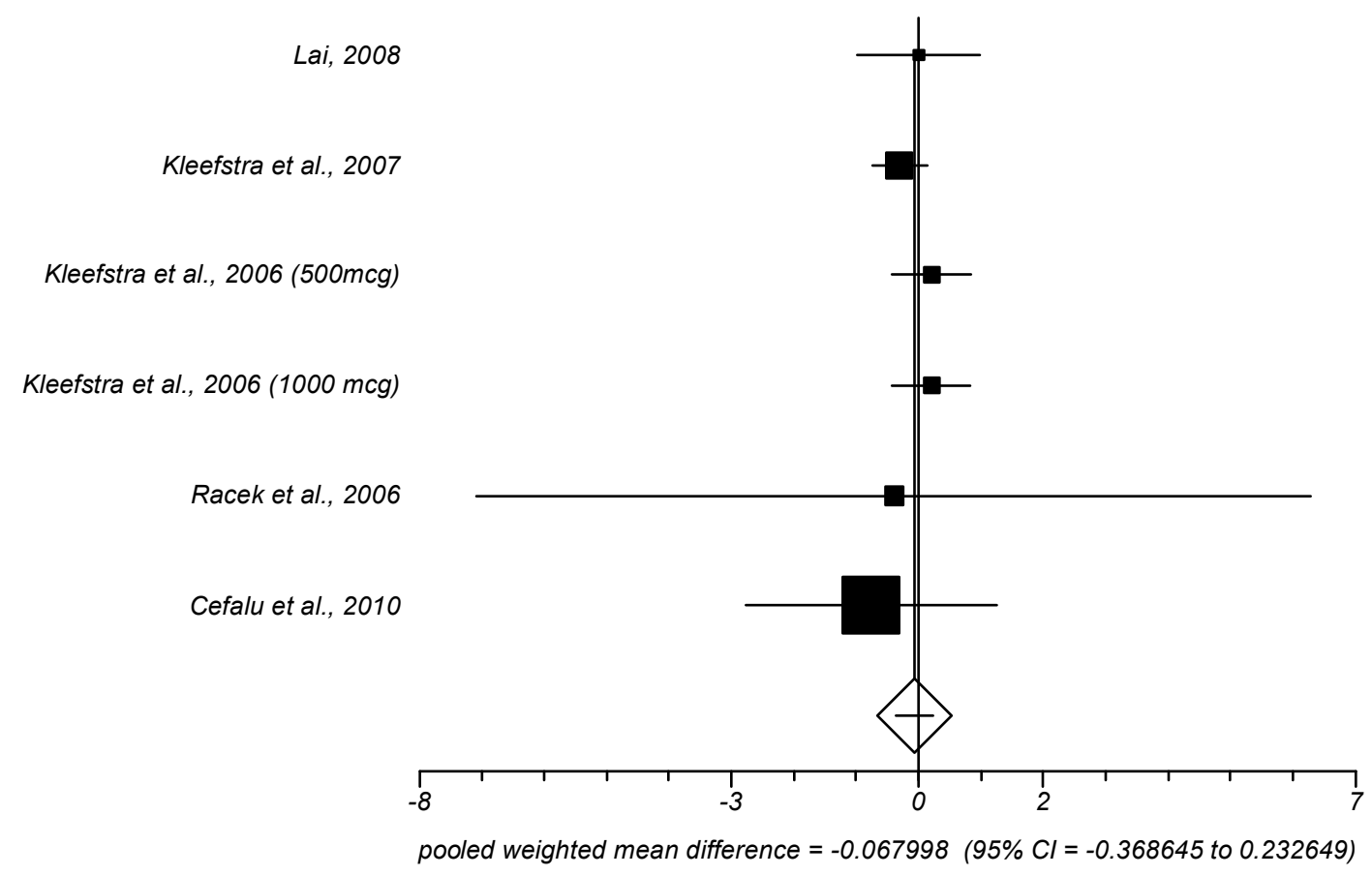

Figure 9-a. Individual and pooled effect size for weighted mean differences for the outcome of " $\Delta \mathrm{BMI}$ " in the studies considering chromium supplement comparing to placebo therapy for diabetic patients

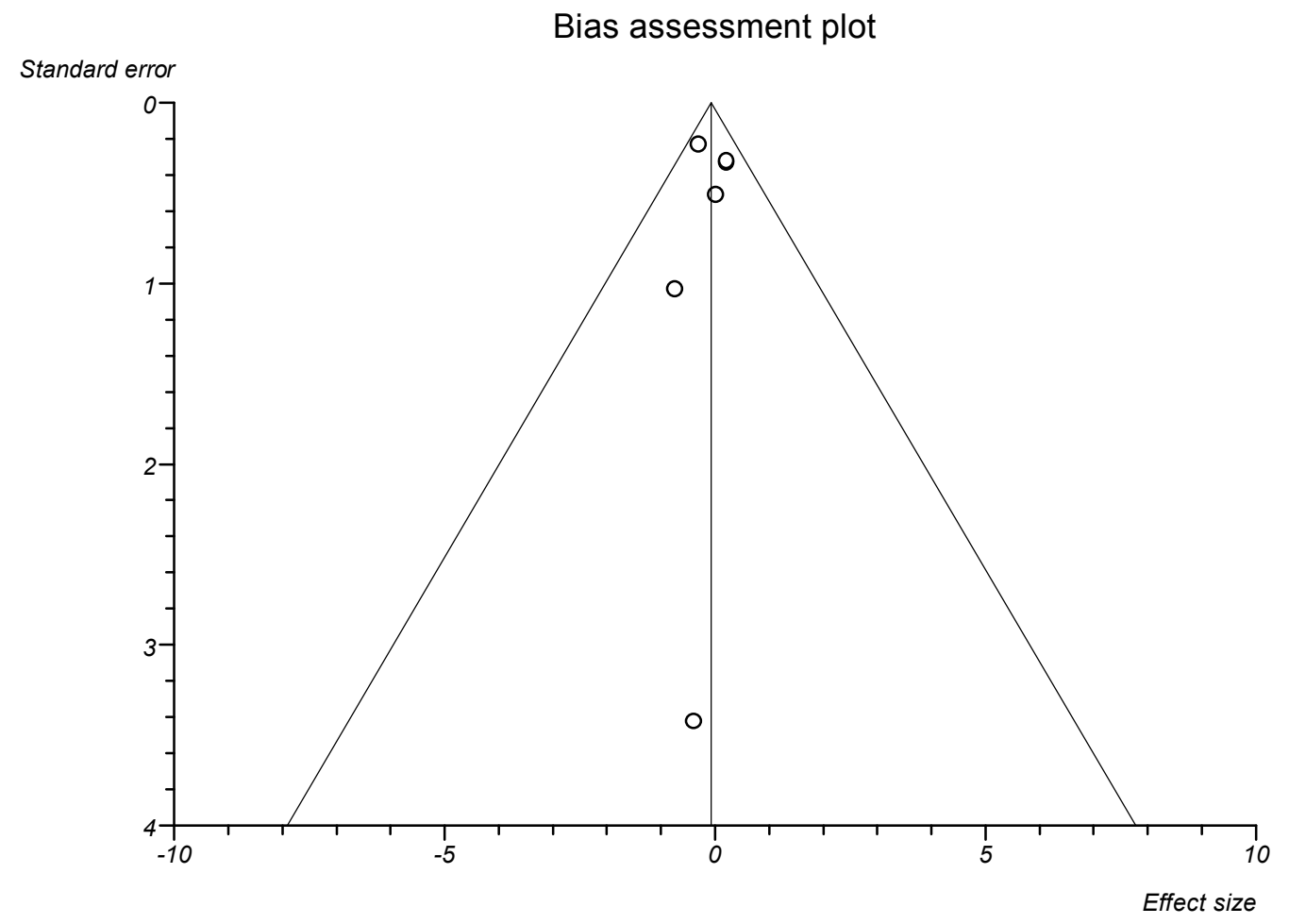

Figure 9-b. Publication bias indicators for the outcome of " $\triangle \mathrm{BMI}$ " in the studies considering chromium supplement comparing to placebo therapy for diabetic patients 


\section{DISCUSSION}

The present meta-analysis indicates that in patients with type $2 \mathrm{DM}, \mathrm{Cr}$ supplementation does not change HbAlc. To reach a better analysis, we eliminated the studies with duration of lesser than three months where changes in HbAlc is not properly observed. The present result on $\mathrm{HbAlc}$ is contrary to a recent review which reported the positive effect of $\mathrm{Cr}$ in $\mathrm{HbAlc}$ reduction by $0.34 \%$ through including 6 RCTs in patients with type 2 DM who had HbAlc higher than 7\% (10). However, the present meta-analysis is specific for type $2 \mathrm{DM}$ patients and includes $\mathrm{Cr}$ with biotin formulations. In the other hand, reviews by two other groups showed $0.6 \%$ and $0.9 \%$ reduction in HbAlc, respectively $(20,21)$. The meta-analysis of Balk et al. included type $2 \mathrm{DM}$ patients and all forms of $\mathrm{Cr}$ formulations. The most controversial issue in that meta-analysis is the inclusion of trials that measured $\mathrm{HbA} 1 \mathrm{c}$ in a period of less than 3 months which seems a major bias but they reported that all included papers showed a significant reduction in HbAlc. In the second review (21), fifteen papers were included while three of them were not RCT. They included both type 1 and type 2 DM, gestational DM, and even steroid-induced diabetes. In the present meta-analysis, four studies showed that $\mathrm{Cr}$ has no significant effect on $\mathrm{HbAlc}$ $(13,15,16,19)$. In two other studies $(17,18)$, a $0.7 \%$ and $1.16 \%$ reductions in $\mathrm{HbAlc}$ was reported for $\mathrm{Cr}$, respectively. In another study (14), Cr could prevent increase of $\mathrm{HbAlc}$ in comparison to $\mathrm{Pl}$. In other studies $(16,17,19), \mathrm{Cr}$ in the form of $\mathrm{Cr}$ enriched yeast was used and only one of them (17) reported significant reduction in $\mathrm{HbAlc}$.

We found that $\mathrm{Cr}$ supplementation significantly reduces FBS up to $7 \mathrm{mmol} / \mathrm{L}(\mathrm{P}<0.0001)$ as reported in three RCTs $(14,17,18)$ with a level of $1.4,1.72$, and $0.5 \mathrm{mmol} / \mathrm{L}$, respectively. Ghosh et al. (2002) explained that because of an increase in insulin action, $\mathrm{Cr}$ could control hyperglycemia in type 2 DM. Among these reports, only Lai et al. (2008) evaluated the Cr-enriched yeast. Also, Patal et al. (2010) reported that FBS decreases post $\mathrm{Cr}$ treatment to $0.67 \mathrm{mmol} / \mathrm{L}$. However, Broadhurst and Domenico (2006) showed a mean FBS of 1.5 $\mathrm{mmol} / \mathrm{L}$.

The present meta-analysis indicates that $\mathrm{Cr}$ has no benefit on lowering TC, HDL-C, LDL-C, VLDL-C, and TG that is consistent with previous reviews $(10,20)$. Furthermore, our meta-analysis indicates that $\mathrm{Cr}$ had no significant effect on BMI. Taking collectively, we can conclude that current evidences do not support positive effects for $\mathrm{Cr}$ in the management of DM as it only reduces FBG that is not sufficient in long-term therapy of DM patients.

\section{ACKNOWLEDGMENT}

Authors thank the assistance of TUMS for doing this meta-analysis. Authors report no conflict of interest.

\section{REFERENCES}

1. Aghili R, Khamseh ME, Malek M, Yarahmadi S, Farshchi A. Structured self monitoring of blood glucose in Iranian people with type 2 diabetes; A cost consequence analysis. Daru, 2012; 20:32.

2. Parkin CG, Davidson JA. Value of self-monitoring blood glucose pattern analysis in improving diabetes outcomes. J Diabetes Sci Technol, 2009; 3(3):500.

3. Psaltopoulou T, Ilias I, Alevizaki M. The role of diet and lifestyle in primary, secondary, and tertiary diabetes prevention: a review of meta-analyses. Rev Diabet Stud, 2010; 7(1):26.

4. Rahimi R, Nikfar S, Larijani B, Abdollahi M. A review on the role of antioxidants in the management of diabetes and its complications. Biomed Pharmacother, 2005; 59(7):365-73.

5. Hosseini A, Abdollahi M. It is time to formulate an antioxidant mixture for management of diabetes and its complications: notice for pharmaceutical industries. Int J Pharmacol, 2012; 8(1):60-1.

6. Cefalu WT, Hu FB. Role of chromium in human health and in diabetes. Diabetes Care, 2004; 27(11):2741-51.

7. Vincent JB. Beneficial effects of chromium (III) and vanadium supplements in diabetes. Nutr Therap Interv Diabetes Metab Syndr, pp 381-391, 2012.

8. Fuhr Jr JP, He H, Goldfarb N, Nash DB. Use of chromium picolinate and biotin in the management of type 2 diabetes: an economic analysis. Dis Manag, 2005; 8(4):265-75.

9. Vincent JB. Mechanisms of chromium action: lowmolecular-weight chromium-binding substance. J Am Coll Nutr, 1999; 18(1):6-12.

10. Patal PC, Cardino MT, Cecilia A. Jimeno CA. A meta-analysis on the effect of chromium picolinate on glucose and lipid profiles among patients with type 2 diabetes mellitus. Philipp J Int Med, 2010; 48(1):32-7.

11. Farshchi A, Nikfar S, Abdollahi M. Concerns on the use of chromium in type 2 diabetes mellitus; needs 
to conduct major meta-analysis. Int $\mathrm{J}$ Pharmacol, 2012; 8(6):470-2.

12. Jadad AR. Randomised controlled trials: a user's guide: BMJ books, London, UK, 1998.

13. Cefalu WT, Rood J, Pinsonat $P$, et al. Characterization of the metabolic and physiologic response to chromium supplementation in subjects with type 2 diabetes mellitus. Metabolism, 2010; 59(5):755.

14. Ghosh D, Bhattacharya B, Mukherjee B, et al. Role of chromium supplementation in Indians with type 2 diabetes mellitus. J Nutr Biochem, 2002; 13(11):690-7.

15. Kleefstra N, Houweling ST, Bakker SJL, et al. Chromium treatment has no effect in patients with type 2 diabetes in a western population a randomized, double-blind, placebo-controlled trial. Diabetes Care, 2007; 30(5):1092-6.

16. Kleefstra N, Houweling ST, Jansman FGA, et al. Chromium treatment has no effect in patients with poorly controlled, insulin-treated type 2 diabetes in an obese western population a randomized, doubleblind, placebo-controlled trial. Diabetes Care, 2006; 29(3):521-5.
17. Lai MH. Antioxidant effects and insulin resistance improvement of chromium combined with vitamin $\mathrm{C}$ and $E$ supplementation for type 2 diabetes mellitus. $\mathrm{J}$ Clin Biochem Nutr, 2008; 43(3):191.

18. Martin J, Wang ZQ, Zhang XH, et al. Chromium picolinate supplementation attenuates body weight gain and increases insulin sensitivity in subjects with type 2 diabetes. Diabetes Care, 2006; 29(8):1826-32.

19. Racek J, Trefil L, Rajdl D, Mudrova V, Hunter D, Senft V. Influence of chromium-enriched yeast on blood glucose and insulin variables, blood lipids, and markers of oxidative stress in subjects with type 2 diabetes mellitus. Biol Trace Elem Res, 2006; 109(3):215-30.

20. Balk EM, Tatsioni A, Lichtenstein AH, Lau J, Pittas AG. Effect of chromium supplementation on glucose metabolism and lipids a systematic review of randomized controlled trials. Diabetes Care, 2007; 30(8):2154-63.

21. Broadhurst CL, Domenico P. Clinical studies on chromium picolinate supplementation in diabetes mellitus-a review. Diabetes Technol Ther, 2006; 8(6):677-87. 


\begin{tabular}{|c|c|c|c|c|c|c|c|c|c|}
\hline Authors & $\begin{array}{c}\text { Year of } \\
\text { publication }\end{array}$ & $\begin{array}{l}\text { Type of } \\
\text { study }\end{array}$ & Sample Size & $\mathbf{N}$ & $\begin{array}{r}\text { Type of } \\
\text { Diabetes }\end{array}$ & Age & Gender & $\begin{array}{l}\text { Dose and type of } \\
\text { Chromium/day }\end{array}$ & $\begin{array}{l}\text { Duration of } \\
\text { Cr. therapy }\end{array}$ \\
\hline Cefalu et al., (13) & 2010 & $\mathrm{RCT}$ & $\begin{array}{l}\text { Cr: } 70 \\
\text { Pl: } 67\end{array}$ & 137 & 2 & $\begin{array}{l}\text { Cr: } 58.7 \pm 1.0 \\
\text { Pl: } 56.1 \pm 1.1\end{array}$ & $\begin{array}{l}\mathrm{Cr}: 37 \mathrm{M} \\
\mathrm{Pl}: 39 \mathrm{M}\end{array}$ & $1000 \mu \mathrm{g} \mathrm{CrP}$ & 6 months \\
\hline Lai, (17) & 2008 & $\mathrm{RCT}$ & $\begin{array}{l}\text { Cr: } 10 \\
\mathrm{Pl}: 10\end{array}$ & 20 & 2 & $<56$ & M:9 & $\begin{array}{l}1000 \mu \mathrm{g} \mathrm{Cr}- \\
\text { enriched yeast }\end{array}$ & 6 months \\
\hline Kleefstra et al., (15) & 2007 & $\mathrm{RCT}$ & $\begin{array}{l}\text { Cr: } 28 \\
\mathrm{Pl}: 28\end{array}$ & 56 & 2 & $\begin{array}{l}\text { Cr: } 68 \pm 8.2 \\
\text { Pl: } 66 \pm 8.6\end{array}$ & $\begin{array}{l}\text { Cr:18 M } \\
\mathrm{Pl}: 17 \mathrm{M}\end{array}$ & $\begin{array}{l}400 \mu \mathrm{g} \mathrm{Cr}- \\
\text { enriched yeast }\end{array}$ & 6 months \\
\hline Martin et al., (18) & 2006 & $\mathrm{RCT}$ & $\begin{array}{l}\text { Cr: } 14 \\
\mathrm{Pl}: 11\end{array}$ & 25 & 2 & $59.7 \pm 8$ & $\mathrm{M}: 17$ & $1000 \mu \mathrm{g} \mathrm{CrP}$ & 6 months \\
\hline \multirow{2}{*}{ Kleefstra et al., (16) } & \multirow{2}{*}{2006} & \multirow{2}{*}{ RCT } & $\begin{array}{l}\text { Cr: } 14 \\
\mathrm{Pl}: 17\end{array}$ & 31 & 2 & $\begin{array}{l}\text { Cr: } 60 \pm 8.8 \\
\text { Pl: } 62 \pm 7.5\end{array}$ & $\begin{array}{l}\mathrm{Cr}: 4 \mathrm{M} \\
\mathrm{Pl}: 10 \mathrm{M}\end{array}$ & $500 \mu \mathrm{g} \mathrm{CrP}$ & 6 months \\
\hline & & & $\begin{array}{l}\text { Cr: } 15 \\
\text { Pl: } 17\end{array}$ & 32 & 2 & $\begin{array}{l}\text { Cr: } 59 \pm 6.4 \\
\text { Pl: } 62 \pm 7.5\end{array}$ & $\begin{array}{l}\mathrm{Cr}: 5 \mathrm{M} \\
\mathrm{Pl}: 10 \mathrm{M}\end{array}$ & $1000 \mu \mathrm{g} \mathrm{CrP}$ & 6 months \\
\hline Racek et al., (19) & 2006 & $\mathrm{RCT}$ & $\begin{array}{l}\text { Cr: } 19 \\
\text { Pl: } 17\end{array}$ & 36 & 2 & - & $\begin{array}{l}\mathrm{Cr}: 7 \mathrm{M} \\
\mathrm{Pl}: 2 \mathrm{M}\end{array}$ & $\begin{array}{l}400 \mu \mathrm{g} \mathrm{Cr} \text {-enriched } \\
\text { yeast }\end{array}$ & 3 months \\
\hline Ghosh et al., (14) & 2002 & RCT & $\begin{array}{l}\text { Cr: } 50 \\
\text { Pl: } 50\end{array}$ & 50 & 2 & $53.5 \pm 10.9$ & M:33 & $400 \mu \mathrm{g} \mathrm{CrP}$ & 3 months \\
\hline
\end{tabular}


J Pharm Pharmaceut Sci (www.cspsCanada.org) 16(1) 99 - 114, 2013

\begin{tabular}{|c|c|c|c|c|c|c|c|c|c|c|c|c|c|c|c|c|}
\hline \multirow[t]{2}{*}{ Study } & \multicolumn{2}{|c|}{ HbA1c, \% } & \multicolumn{2}{|c|}{$\begin{array}{l}\text { Fasting } \\
\text { glucose }\end{array}$} & \multicolumn{2}{|c|}{ Total-C } & \multicolumn{2}{|c|}{ HDL-C } & \multicolumn{2}{|c|}{ LDL-C } & \multicolumn{2}{|c|}{ TG } & \multicolumn{2}{|c|}{ VLDL-C } & \multicolumn{2}{|c|}{ BMI } \\
\hline & $\mathrm{Cr}$ & PI & $\mathrm{Cr}$ & Pl & $\mathrm{Cr}$ & PI & $\mathrm{Cr}$ & PI & $\mathrm{Cr}$ & PI & $\mathrm{Cr}$ & PI & $\mathrm{Cr}$ & PI & $\mathrm{Cr}$ & PI \\
\hline \multirow{3}{*}{$\begin{array}{l}\text { Cefalu et al., } \\
\text { (13) }\end{array}$} & -0.72 & 0.13 & -1.10 & 0.10 & & & & & & & & & 1.19 & -0.11 & -0.05 & 0.71 \\
\hline & \pm & \pm & \pm & \pm & - & - & - & - & - & - & - & - & \pm & \pm & \pm & \pm \\
\hline & 4.16 & 2.67 & 4.87 & 2.95 & & & & & & & & & 5.58 & 3.18 & 5.55 & 6.45 \\
\hline \multirow{3}{*}{$\begin{array}{l}\text { Lai, } \\
\text { (17) }\end{array}$} & -0.70 & 0.10 & -1.40 & -0.02 & & & & & & & & & & & -0.10 & -0.10 \\
\hline & \pm & \pm & \pm & \pm & - & - & - & - & - & - & - & - & - & - & \pm & \pm \\
\hline & 0.53 & 0.56 & 0.66 & 1.02 & & & & & & & & & & & 1.20 & 1.06 \\
\hline \multirow{3}{*}{$\begin{array}{l}\text { Kleefstra et al., } \\
(15)\end{array}$} & 0.51 & 0.26 & 0.90 & 0.70 & 0.46 & 0.23 & 0.14 & 0.11 & 0.31 & 0.06 & 0.03 & 0.13 & & & 0.10 & 0.40 \\
\hline & \pm & \pm & \pm & \pm & \pm & \pm & \pm & \pm & \pm & \pm & \pm & \pm & - & - & \pm & \pm \\
\hline & 0.64 & 0.47 & 2.30 & 1.70 & 0.42 & 0.64 & 0.18 & 0.15 & 0.40 & 0.63 & 0.49 & 0.68 & & & 0.80 & 0.90 \\
\hline \multirow[b]{2}{*}{$\begin{array}{l}\text { Martin et al., } \\
\text { (18) }\end{array}$} & -1.16 & -0.44 & -1.72 & -0.62 & & & & & & & 012 & 0.34 & & & & \\
\hline & $\begin{array}{c} \pm \\
1.42\end{array}$ & $\begin{array}{c} \pm \\
1.43\end{array}$ & $\begin{array}{c} \pm \\
1.50\end{array}$ & $\begin{array}{c} \pm \\
1.46\end{array}$ & - & - & - & - & - & - & $\begin{array}{c}0.12 \pm \\
0.52\end{array}$ & $\begin{array}{c} \pm \\
0.66\end{array}$ & - & - & - & - \\
\hline \multirow{3}{*}{$\begin{array}{l}\text { Kleefstra et al., } \\
500 \mu g(16)\end{array}$} & -0.50 & -0.30 & & & -0.20 & 0.20 & -0.10 & 0.10 & -0.10 & 0.30 & -0.10 & 1.01 & & & 0.20 & 0.00 \\
\hline & \pm & \pm & - & - & \pm & \pm & \pm & \pm & \pm & \pm & \pm & \pm & - & - & \pm & \pm \\
\hline & 0.80 & 0.80 & & & 0.80 & 1.20 & 0.30 & 0.10 & 0.60 & 0.70 & 0.90 & 4.30 & & & 1.10 & 0.70 \\
\hline \multirow[b]{2}{*}{$\begin{array}{l}\text { Kleefstra et al., } \\
1000 \mu \mathrm{g}(16)\end{array}$} & -0.30 & -0.30 & & & 0.10 & 0.20 & 0.10 & 0.10 & 0.00 & 0.30 & -0.20 & 1.00 & & & $020+$ & 0.00 \\
\hline & $\begin{array}{c} \pm \\
0.90\end{array}$ & $\begin{array}{c} \pm \\
0.90\end{array}$ & - & - & $\begin{array}{c} \pm \\
0.40\end{array}$ & $\begin{array}{c} \pm \\
1.30\end{array}$ & $\begin{array}{c} \pm \\
0.10\end{array}$ & $\begin{array}{c} \pm \\
0.20\end{array}$ & $\begin{array}{c} \pm \\
0.40\end{array}$ & $\begin{array}{c} \pm \\
0.80\end{array}$ & $\begin{array}{c} \pm \\
0.50\end{array}$ & $\begin{array}{c} \pm \\
4.40\end{array}$ & - & - & $\begin{array}{c}0.20 \pm \\
1.00\end{array}$ & $\begin{array}{c} \pm \\
0.80\end{array}$ \\
\hline \multirow{3}{*}{ Racek et al., (19) } & -0.30 & 0.17 & & 0.80 & & & -0.12 & 0.03 & -0.01 & -0.04 & -0.14 & -0.04 & 0.07 & 0.24 & -0.45 & -0.05 \\
\hline & \pm & \pm & $\begin{array}{c}-0.43 \pm \\
280\end{array}$ & \pm & - & - & \pm & \pm & \pm & \pm & \pm & \pm & \pm & \pm & \pm & \pm \\
\hline & 2.25 & 2.32 & 2.89 & 3.74 & & & 1.23 & 1.37 & 0.43 & 0.53 & 0.98 & 1.04 & 1.38 & 2.39 & 8.57 & 11.83 \\
\hline \multirow{3}{*}{ Ghosh et al., (14) } & 0.01 & 0.7 & -0.5 & 0.4 & -0.7 & -0.3 & -0.2 & -0.2 & -0.5 & -0.1 & 0.2 & 0.3 & & & & \\
\hline & \pm & \pm & \pm & \pm & \pm & \pm & \pm & \pm & \pm & \pm & \pm & \pm & - & - & - & - \\
\hline & 2.96 & 2.75 & 3.67 & 4.11 & 2.36 & 2.26 & 0.42 & 0.5 & 2.14 & 1.9 & 1.27 & 1.27 & & & & \\
\hline
\end{tabular}

